Louisiana State University

LSU Digital Commons

Faculty Publications

Department of Biological Sciences

$1-1-2015$

\title{
Fat in flames: Influence of cytokines and pattern recognition receptors on adipocyte lipolysis
}

Ryan W. Grant

College of Health and Human Sciences

Jacqueline M. Stephens

Pennington Biomedical Research Center

Follow this and additional works at: https://digitalcommons.Isu.edu/biosci_pubs

\section{Recommended Citation}

Grant, R., \& Stephens, J. (2015). Fat in flames: Influence of cytokines and pattern recognition receptors on adipocyte lipolysis. American Journal of Physiology - Endocrinology and Metabolism, 309 (3), E205-E213. https://doi.org/10.1152/ajpendo.00053.2015

This Article is brought to you for free and open access by the Department of Biological Sciences at LSU Digital Commons. It has been accepted for inclusion in Faculty Publications by an authorized administrator of LSU Digital Commons. For more information, please contact ir@lsu.edu. 


\title{
CALL FOR PAPERS $\mid$ Metabolic Control by Inflammation and Immunity
}

\section{Fat in flames: influence of cytokines and pattern recognition receptors on adipocyte lipolysis}

\author{
Ryan W. Grant ${ }^{1}$ and Jacqueline M. Stephens ${ }^{2,3}$ \\ ${ }^{1}$ Department of Nutrition Science, Purdue University, West Lafayette, Indiana; ${ }^{2}$ Adipocyte Biology Lab, Pennington \\ Biomedical Research Center, Baton Rouge, Louisiana; and ${ }^{3}$ Department of Biological Sciences, Louisiana State University, \\ Baton Rouge, Louisiana
}

Submitted 5 February 2015; accepted in final form 3 June 2015

\begin{abstract}
Grant RW, Stephens JM. Fat in flames: influence of cytokines and pattern recognition receptors on adipocyte lipolysis. Am J Physiol Endocrinol Metab 309: E205-E213, 2015. First published June 9, 2015; doi:10.1152/ajpendo.00053.2015.Adipose tissue has the largest capacity to store energy in the body and provides energy through the release of free fatty acids during times of energy need. Different types of immune cells are recruited to adipose tissue under various physiological conditions, indicating that these cells contribute to the regulation of adipose tissue. One major pathway influenced by a number of immune cells is the release of free fatty acids through lipolysis during both physiological (e.g., cold stress) and pathophysiological processes (e.g., obesity, type 2 diabetes). Adipose tissue expansion during obesity leads to immune cell infiltration and adipose tissue remodeling, a homeostatic process that promotes inflammation in adipose tissue. The release of proinflammatory cytokines stimulates lipolysis and causes insulin resistance, leading to adipose tissue dysfunction and systemic disruptions of metabolism. This review focuses on the interactions of cytokines and other inflammatory molecules that regulate adipose tissue lipolysis during physiological and pathophysiological states.
\end{abstract}

adipocyte; lipolysis; cytokines

LIPOLYSIS IS THE HYDROLYSIS of triglycerides (TGs) to free fatty acids (FFAs) and glycerol. A variety of enzymes are involved in this process that vary depending on the cell type. In adipocytes, lipolysis occurs via the actions of adipose triglyceride lipase (ATGL), hormone-sensitive lipase (HSL), and monoglyceride lipase (Fig. 1). The lipolytic pathway is highly regulated by both hormonal and nutritional factors. Stimulation of lipolysis provides FFA release from adipocytes that is critical in times of negative energy balance, including exercise and fasting. However, the inability to inhibit lipolysis when FFA are not needed can have serious metabolic consequences, including the development of type 2 diabetes mellitus (T2DM). A great deal of progress on dissecting the molecular regulation of adipose tissue lipolysis has occurred in the past two decades and has been recently reviewed $(2,52)$. The regulation of lipolysis occurs by multiple mechanisms, including modulation of transcription and translation, posttranslational modifications, cellular localization, protein-protein interactions, and protein stability/degradation $(2,52)$. There are many stimulators of adipocyte lipolysis, including catecholamines, natriuretic peptides, growth hormone, glucocor-

Address for reprint requests and other correspondence: J. M. Stephens, Pennington Biomedical Research Center, Adipocyte Biology Laboratory, 6400 Perkins Rd., Baton Rouge, LA 70808 (e-mail: jsteph1@1su.edu). ticoids, and TNF $\alpha$. Whereas the primary antilipolytic pathway is regulated by insulin, the mobilization of FFAs from adipose tissue is recognized as playing an important role in insulin resistance and T2DM and supports the notion that dysregulation of adipose tissue lipolysis is a critical factor in metabolic disease states.

The primary source of lipolytic regulators produced in adipose tissue are cytokines. Table 1 summarizes influential cytokines that regulate adipocyte lipolysis. Enhanced adipose tissue cytokine release during obesity drives low-grade inflammation, resulting in systemic impairments of glucose and insulin tolerance and lipid metabolism (53). However, the metabolic response to obesity is varied, and there is a considerable proportion of obese individuals that lack obesity-associated disease and are metabolically healthy (57). Recent studies implicate lipid storage, extracellular matrix composition, and inflammation as factors that distinguish metabolically healthy from metabolically unhealthy obesity $(31,38,47,58)$. Secretion of cytokines from immune cells in adipose tissue appears to be a key component linking inflammation, lipid storage, unregulated lipolysis, ectopic fat and metabolic disease through both paracrine and endocrine mechanisms (42). Storage of lipids in adipose tissue protects against the development of metabolic disease (33), while the inability to store lipids in adipose tissue redistributes body fat leading to ectopic storage and metabolic impairment (6). This review will focus 
Fig. 1. TNF $\alpha$ signaling shapes lipid metabolism. Signaling of TNF $\alpha$ through TNFR1 leads to activation of multiple signaling pathways including NF- $\kappa \mathrm{B}$ and ERKs. Activation of these pathways leads to transcriptional changes resulting in reduced expression of lipoprotein lipase. $\mathrm{TNF} \alpha$ signaling induces a loss of the lipid droplet protein perilipin and activation of adipose triglyceride lipase (ATGL) and hormone-sensitive lipase (HSL). These enzymes act on triacylglycerol (TAG) and diacylglycerol (DAG), resulting in the release of free fatty acids (FA). To further promote lipolysis, TNF $\alpha$ activates proteasomedependent degradation of $\mathrm{G}_{\mathrm{i}}$ proteins that have the ability to reduce antilipolytic adenosine signaling.

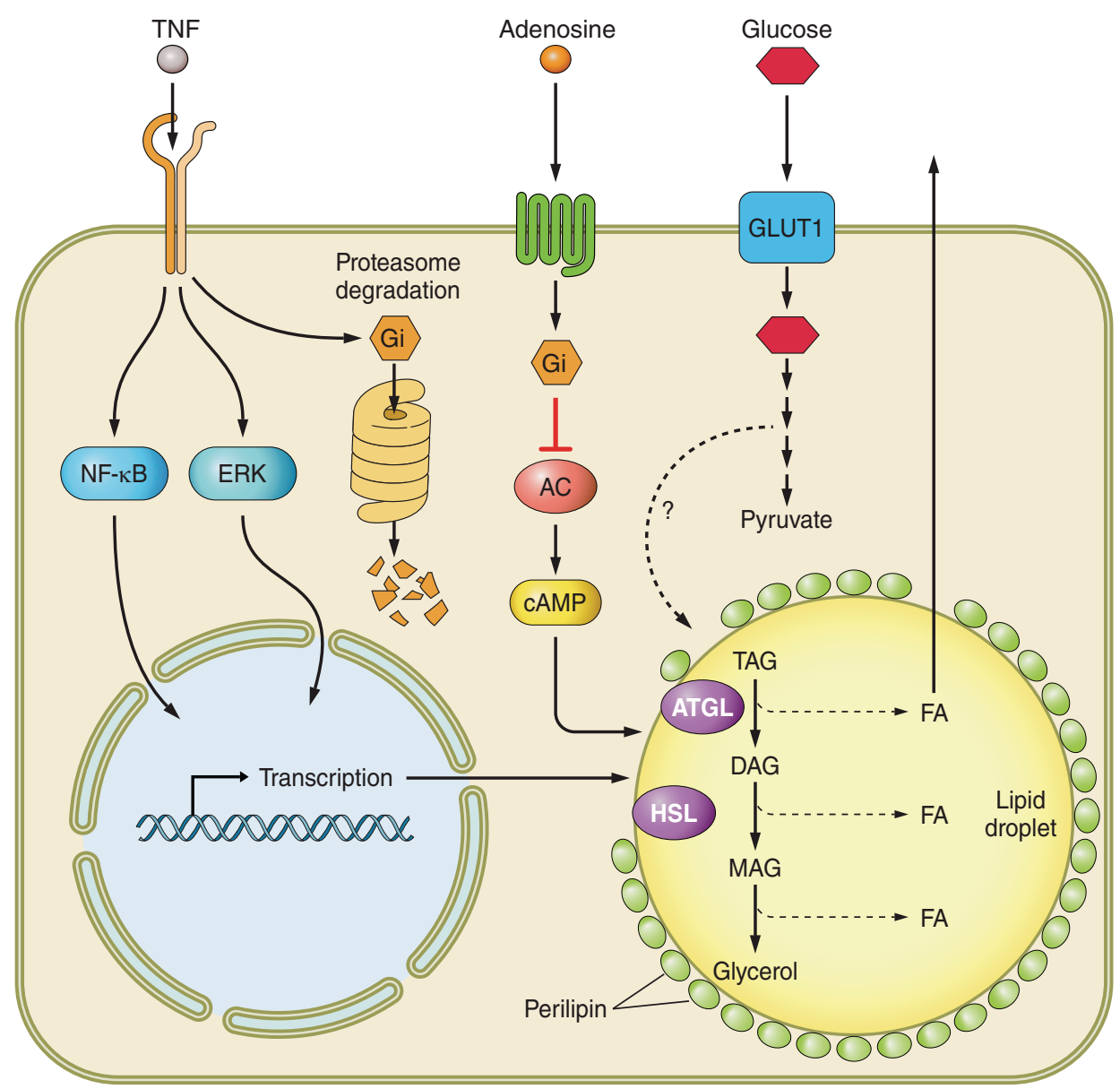

on how cytokines influence adipocyte lipolysis and how this relates to the development of insulin resistance and obesity associated comorbidities.

\section{Tumor Necrosis Factor- $\alpha$-Stimulated Lipolysis}

Tumor necrosis factor- $\alpha(\mathrm{TNF} \alpha)$ was the first cytokine shown to be produced in adipose tissue and increased in conditions of obesity and insulin resistance (28). TNF $\alpha$ is a potent mediator of adipose tissue and systemic insulin resistance (28). TNF $\alpha$ induces insulin resistance through multiple mechanisms that include inhibition of adipogenesis (81); inhi- bition of insulin-sensitive glucose uptake in mature adipocytes (27); inhibition of glucose transporter 4 (GLUT4) (76), insulin receptor (IR), and insulin receptor substrate-1 (IRS-1) expression (75); and the ability to alter IR and IRS-1 phosphorylation (27). Accordingly, animals that lack TNF $\alpha$ (26) have improved systemic insulin sensitivity and glucose tolerance. TNF $\alpha$ signals through $\mathrm{TNF} \alpha$ receptors (TNFR) 1 and -2 and leads to transcriptional changes mediated through activation of nuclear factor- $\mathrm{\kappa} \mathrm{B}(\mathrm{NF}-\kappa \mathrm{B})$ and extracellular signal-related kinase (ERK) signaling (Figs. 1 and 2). Mice that lack TNFR1 and -2 are protected against insulin resistance and glucose intolerance

Table 1. Influence of cytokines on lipolysis

\begin{tabular}{|c|c|c|c|c|}
\hline Symbol & Cytokine Name & Model & Effect on Lipolysis & References \\
\hline $\mathrm{TNF} \alpha$ & Tumor necrosis factor $\alpha$ & Rat adipocytes, human adipocytes, 3T3-L1 adipocytes & $\uparrow$ & $16,17,41,71$ \\
\hline IL- $1 \beta / \mathrm{IL}-1 \alpha$ & Interleukin-1 $(\beta$ and $\alpha)$ & 3T3-F442A adipocytes, 3T3-L1 adipocytes & $\uparrow$ & 11,60 \\
\hline IL-18 & Interleukin-18 & Not studied & $\leftrightarrows$ or $\downarrow$ (prediction) & \\
\hline IL-6 & Interleukin-6 & 3T3-L1 adipocytes & $\uparrow$ & 30,56 \\
\hline LIF & Leukemia inhibitory factor & 3T3-F442A adipocytes, 3T3-L1 adipocytes & $\uparrow$ & 48 \\
\hline OSM & Oncostatin $\mathrm{M}$ & Not studied & $\uparrow$ (prediction) & \\
\hline CNTF & Ciliary neurotrophic factor & 3T3-L1 adipocytes & $\leftrightarrows$ & 5 \\
\hline CT-1 & Cardiotrophin 1 & Mouse adipocytes, 3T3-L1 adipocytes & $\leftrightarrows$ or $\uparrow$ & 44,49 \\
\hline IL-4 & Interleukin-4 & 3T3-L1 adipocytes & $\uparrow$ (direct or indirect?) & 51,82 \\
\hline IL-10 & Interleukin-10 & Not directly studied & $\downarrow$ (indirect) & 45 \\
\hline IL-15 & Interleukin-15 & Porcine adipocytes & $\uparrow$ & 1 \\
\hline IL-17a & Interleukin-17a & Human adipocytes & $\uparrow$ & 70 \\
\hline IL-21 & Interleukin-21 & 3T3-L1 adipocytes & $\downarrow$ (indirect) & 8 \\
\hline IFN $\gamma$ & Interferon- $\gamma$ & 3T3-F422A adipocytes & $\uparrow$ & 11 \\
\hline
\end{tabular}




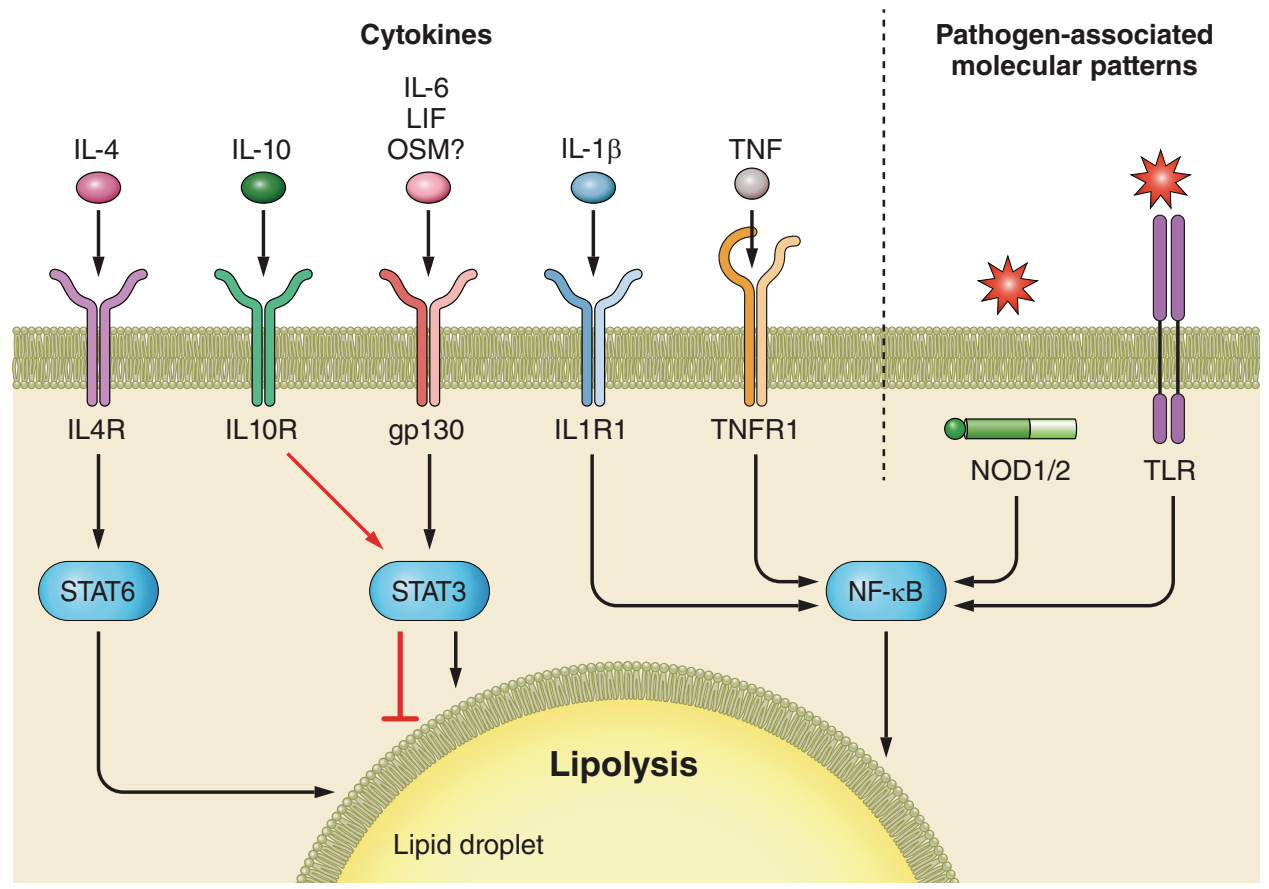

Fig. 2. Lipolysis cytokines and signaling proteins. Adipose tissue produces a variety of cytokines that can activate lipolysis in adipocytes. In addition to cytokines, pathogenassociated molecular patterns can activate adipocyte lipolysis. These cytokines bind to specific receptors and activate signaling pathways that contribute to lipolysis. Presented are the cytokines, receptors, and conical signaling pathways that contribute to lipolysis. LIF, leukemia inhibitory factor; OSM, oncostatin M; NOD, nucleotidebinding oligomerization domain-containing protein; TLR, Toll-like receptor.

(85). In both human and murine adipocytes, signaling through TNFR1 appears to have the largest contribution to insulin resistance $(55,90)$.

Adipose tissue macrophages (ATMs) produce the majority of TNF $\alpha$ in adipose tissue (93). It has been known for over a decade that adipose tissue expression of $\mathrm{TNF} \alpha$ increases with macrophage number and is associated with the development of insulin resistance $(25,79)$. ATMs increase acutely during times of lipolysis, including fasting and pharmacological activation (37). During a weight loss time course in diet-induced obese C57BL/6 mice, ATMs are reduced by day 21 and continue to decrease until day 60 (37). Interestingly, over this same time course, tissue $\mathrm{TNF} \alpha$ levels are not reduced, as would be expected with decreased ATMs (37). Whether TNF $\alpha$ expression is increased at the level of gene expression, or a different cell type is contributing to the maintenance of TNF $\alpha$ expression, is not known. However, it is well established that $\mathrm{TNF} \alpha$ reduces lipoprotein lipase (LPL) expression in adipocytes (32). The coupling of reduced LPL expression and lipolysis may be necessary for fat pad contraction during weight loss. It is unknown whether the expressions of TNF $\alpha$ and proinflammatory cytokines in adipose tissue revert to that of lean phenotype after prolonged weight loss. Future studies will likely investigate the impact of inflammatory cytokines on subsequent weight cycling and lipid distribution.

In addition to prominent effects on insulin sensitivity and LPL in adipocytes, $\mathrm{TNF} \alpha$ also alters adipocyte metabolism through the induction of lipolysis in many species including humans $(16-18,65,71,73,97)$. Unlike the acute effects of $\beta$-adrenergic signaling-induced lipolysis, $\mathrm{TNF} \alpha$-induced lipolysis occurs $\sim 3 \mathrm{~h}$ after treatment, indicating a transcriptiondependent mechanism (96). Multiple mechanisms have been demonstrated to play a role in $\mathrm{TNF} \alpha$-induced lipolysis, including intracellular signaling cascades, metabolites, and lipid droplet-associated proteins (Fig. 1). Both ATGL and HSL contribute to TNF $\alpha$-induced lipolysis (96). To achieve maxi- mal lipolysis in response to $\mathrm{TNF} \alpha$, the ATGL-regulating protein comparative gene identification 58 is required and expression of the inhibitory protein $\mathrm{G}_{0} / \mathrm{G}_{1}$ switch 2 must be decreased in 3T3-L1 adipocytes (96). Treatment of adipocytes with $\mathrm{TNF} \alpha$ activates ERK signaling pathways, and blocking ERK activation results in a reduction of lipolysis in primary human adipocyte and 3T3-L1 adipocytes $(72,97)$. ERK inhibition is also associated with a $\mathrm{TNF} \alpha$-induced reduction of the lipid droplet-associated protein perilipin 1 (97). In primary human adipocytes, inhibition of NF-кB subunit p65 nuclear translocation results in a reduction of glycerol release in response to $\mathrm{TNF} \alpha$ (41). Interestingly, in addition to reducing lipolysis, the combination of $\mathrm{TNF} \alpha$ and $\mathrm{NF}-\kappa \mathrm{B}$ inhibition resulted in a significant decrease of perilipin and HSL gene and protein expression, but did not alter ATGL gene expression (41).

Metabolites also play a role in regulating lipolysis. Adenosine reduces lipolysis through activation of $G_{i}$ proteins that inhibit adenylyl cyclase (Fig. 1) (24). In primary rat adipocytes, TNF $\alpha$ reduces $G_{i}$ proteins in a proteasome dependent manner $(3,16)$ that results in a loss of inhibitory signaling through the adenosine A1 receptors and enhanced lipolysis. In 3T3-L1 adipocytes, the lipolytic effects of $\mathrm{TNF} \alpha$ require glucose and lipolysis increases with greater concentrations of glucose in the cell culture media (18). Additionally, this effect of glucose is specific to sugars that can support lactate production. Like glucose, mannose also supports higher rates of glycerol release and release of lactate from adipocytes, whereas sugars that do not support lactate formation (galactose and fructose) limit $\mathrm{TNF} \alpha$-induced glycerol release (18). Consistent with the previous observations, inhibition of glycolysis inhibits glycerol release in response to $\mathrm{TNF} \alpha$ (18). Phosphorylation of ERKs in response to TNF $\alpha$ occurs in both the presence and the absence of glucose, and a decrease in perilipin occurs in the presence and absence of glucose (18). These data indicate that metabolites produced by glycolysis support lipolysis; however, the acute signaling and mechanisms underlying 
these findings remain unknown. It is interesting to note that the induction of lipolysis via $\beta$-adrenergic receptors does not require glucose (18). Collectively, these studies indicate that the NF-кB and ERK signaling pathways as well as glucose metabolism contribute to $\mathrm{TNF} \alpha$-induced lipolysis. Interestingly, coculture of macrophages with 3T3-L1 adipocytes causes increased basal glucose uptake in 3T3-L1 adipocytes, increased GLUT1 protein content, and insulin resistance (46). This insulin resistance is significantly rescued by antibodymediated TNF depletion (46). Currently, the effects of TNFtargeted therapies on lipolysis have not been studied in clinical trials. However, with the increased use of these medications for inflammatory conditions, there may be potential to examine their effects. The influence of $\mathrm{TNF} \alpha$ on lipolysis has been demonstrated across multiple cell lines, but the importance of each pathway is not known and likely varies depending on the type and/or source of adipocytes. Integration of these pathways is needed to understand the acute regulation of $\mathrm{TNF} \alpha$-induced lipolysis and how it is linked to substrate metabolism.

\section{Interleukin-1 $\beta$, Interleukin-1 $\alpha$, Interleukin-18}

The secretion of both interleukin (IL)-1 $\beta$ and IL-18 is regulated by caspase-1 (68). In the obese condition, activation of the nucleotide-binding oligomerization domain-like receptor, pyrin domain-containing (NLRP3) inflammasome regulates caspase- 1 activation to influence the synthesis of IL- $1 \beta$ and IL-18 (88). The NLRP3 inflammasome is activated in response to metabolic danger signals (e.g., ceramides, fatty acids, and hyperglycemia) and thus plays an important role in linking impairments of metabolism during obesity and T2DM with cytokine secretion and insulin resistance $(88,94,99)$. Knockout of the NLRP3 inflammasome reduces adipose tissue inflammation during diet-induced obesity and leads to improvements in insulin sensitivity in skeletal muscle, liver, and adipose tissue $(78,88,94)$. Although the NLRP3 inflammasome is primarily expressed in macrophages and dendritic cells, its components are present in adipocytes (19). Caspase$1^{-1-}$ and NLRP3 ${ }^{-1-}$ adipocytes have increased capacity to store lipids and increased expression of GLUT4, adiponectin, and peroxisome proliferator-activated receptor- $\gamma$ (PPAR $\gamma$ ), which are associated with improved adipose tissue function (77). The NLRP3 inflammasome and caspase-1 influence adipogenesis and the storage of lipids in adipocytes; however, the in vivo function of adipocyte-expressed NLRP3 and its contribution to insulin sensitivity have not been investigated.

Initial studies using recombinant IL-1 demonstrated its ability to increase lipolytic activity in adipocytes $(11,60)$. More recently, studies in mouse and human primary adipocytes showed that IL-1 $\beta$ represses adipogenesis and decreases the expression of PPAR $\gamma$, adiponectin, and $\operatorname{GLUT4}(39,77)$. In response to chronic treatment with IL-1 $\beta$, mouse 3T3-L1 and 3T3-F442A and human adipocytes have reduced phosphorylation of IR, IRS-1, protein kinase B (Akt), and ERK1/2 in a dose-dependent manner $(39,77)$. Along with changes in insulin signaling, IL-1 $\beta$ also increases the basal rate of lipolysis in 3T3-L1 but not 3T3-F442A adipocytes (39). IL-1 $\alpha$ is known to have similar effects on insulin resistance (21). IL- $1 \alpha$ and $-\beta$ signal through IL-1 receptor 1 , whose activation results in NK-кB-dependent transcription (Fig. 2). Mice that lack IL-1 receptor 1 are protected against inflammation associated with diet-induced obesity and have improved glucose tolerance. The effects induced by IL- $1 \beta$ and IL- $1 \alpha$ may be in part mediated by their ability to induce IL-6 expression and subsequently signal transducer and activator of transcription 3 (STAT3) activation, which are known to contribute to lipolysis $(13,84)$. Unlike IL-1 $\beta$ and IL- $1 \alpha$, IL-18 does not influence adipogenesis or appear to cause insulin resistance in adipocytes (77). IL-18 modestly enhances insulin-stimulated glucose uptake and modestly counteracts the reduction of insulin-stimulated glucose uptake induced by TNF $\alpha$ in 3T3-L1 adipocytes (89). Yet, there is also evidence that IL-18 suppresses adiponectin gene expression and secretion in cultured mouse adipocytes (4). It is likely that IL-18 does not share the lipolytic properties of IL-1 $\beta$ and IL- $1 \alpha$, since mice that lack IL-18 develop obesity and insulin resistance due to hyperphagia (50). There is growing interest in IL-1-targeted therapies for the management of inflammatory disease. Interestingly, glyburide, an insulin secretagogue, is also an inhibitor of inflammasome activation (40). It appears to have anti-inflammatory effects in addition to its ability to increase insulin secretion and lower blood glucose, TGs, and FFAs. The contributions of inflammasome inhibition versus effects on insulin secretion have not been examined. Anakinra, an IL-1 receptor antagonist, has been shown to enhance insulin secretion and lower $\mathrm{HbA}_{1 \mathrm{C}}$; however, it has minimal effects on TGs and blood cholesterol (40). Thus, IL-1 $\beta$ and IL- $1 \alpha$ and IL-18 appear to have divergent metabolic effects that merit further study to determine the impact of inflammasome activation on adipocytes and adipose tissue.

\section{Glycoprotein 130 Cytokines}

The IL-6 family of cytokines is a group of functionally and structurally related proteins that consist of IL-6, IL-11, IL-27, leukemia inhibitory factor (LIF), oncostatin M (OSM), ciliary neurotrophic factor (CNTF), cardiotrophin-1 (CT-1), cardiotrophin-like cytokine (CLC), and neuropoietin (NP) (22). These cytokines regulate a variety of complex biological processes. Because all IL-6 family members utilize glycoprotein 130 (gp130) receptor and it is required for signaling, the IL-6 family is commonly referred to as gp130 cytokines (10). IL-6 family cytokines utilize gp130 and other receptor proteins, including the oncostatin receptor and LIF receptor. Once activated, signaling by gp130 family members causes STAT3 translocation to the nucleus and STAT3-dependent transcription (Fig. 2). It is well known that IL-6 concentrations are increased in adipose tissue, and circulating levels are associated with metabolic impairments during obesity and T2DM (59, 91). However, IL-6 levels are also increased during exercise and may contribute to some of the beneficial effects of physical activity on health (54). A study in humans demonstrated that IL-6, at concentrations that do not affect catecholamines or $\mathrm{TNF} \alpha$, induces lipolysis and enhances fatty acid oxidation (87). In older adults, IL-6 increased the rate of appearance of FFAs as well as fatty acid disposal, further confirming an in vivo effect of IL-6 on adipose tissue lipolysis and fatty acid oxidation in humans (56). Mouse models of IL-6 deletion have generated contradictory data. It has been reported that IL- $6^{-1-}$ mice develop mature-onset obesity (92), whereas others have not observed this effect (7). Treatment of 3T3-L1 adipocytes with IL-6 increases glycerol and NEFA release. However, there is variation in the degree of magnitude ob- 
served across studies $(30,56)$. Also, IL-6-induced lipolysis appears to be influenced by other hormonal factors. The combined treatment of dexamethasone and growth hormone is capable of inhibiting IL-6-induced lipolysis (56). It is noteworthy that the in vivo changes in lipolysis and lipid oxidation in humans can be mimicked in cell culture models. In addition to the lipolytic actions observed in adipocytes, treatment of L6 myotubes with IL-6 increases palmitate oxidation (56). A role for IL-6 in energy expenditure was demonstrated in IL-6 $6^{-1-}$ mice under cold stress. IL- $6^{-/-}$mice have reduced energy expenditure under basal conditions and when challenged with cold stress have a reduced ability to maintain core temperature (95). It is interesting that uncoupling protein-1 (UCP1) expression in brown adipose tissue was not different in wild-type (WT) and IL- $6^{-1-}$ mice, indicating a capacity for thermogenesis; however, it may be that the delivery of substrates to the tissue was reduced. The contribution of IL-6 to cold-induced lipolysis in white adipose tissue for sustaining energy production during cold-induced thermogenesis has not been addressed.

Although the effects of IL-6 on lipolysis have been studied, it is only one member of the larger gp130 cytokine family, and the effects of other cytokine members of this family on adipose tissue lipolysis have not been well studied. LIF modifies adipocyte lipid metabolism by reducing LPL activity, slightly increasing lipogenesis and modestly increasing lipolysis in cultured murine adipocytes (48). CT-1 has recently been shown to be important in the control of glucose homeostasis and metabolism, as mice that lack CT-1 have reduced energy expenditure and increased body weight (49). CT-1 ${ }^{-1-}$ mice have reduced expression of ATGL and HSL in adipose tissue at $12 \mathrm{mo}$ of age and increased basal lipolysis. However, when adipocytes were isolated from 2-mo-old WT and CT-1 ${ }^{-1-}$ mice, there were no differences in basal lipolysis, indicating that changes in adipocyte lipolysis were secondary to weight gain (49). Delivery of recombinant CT-1 $\left(0.2 \mathrm{mg} \cdot \mathrm{kg}^{-1} \cdot \mathrm{day}^{-1}\right)$ to $o b / o b$ mice for 10 days was shown to enhance glycerol release compared with pair-fed mice. Recombinant CT-1 activates lipolysis in 3T3-L1 adipocytes (44). CNTF remodels adipocyte metabolism by promoting mitochondrial biogenesis and reducing fatty acid esterification and lipogenesis; however, it had no effects on lipolysis (5). In general, the effects of gp130 cytokines on lipolysis have received minimal investigation. Hopefully, future studies will address the effects of this family of cytokines on adipocyte lipolysis, as one of these cytokines, OSM, is produced in immune cells in adipose tissue and is highly regulated in mouse and human obesity and T2DM (66).

\section{Pattern Recognition Receptors}

The systemic response to pattern-associated molecular patterns (PAMPs) found on pathogens, including bacteria, viruses, and fungi, is characterized by the mobilization of energy resources including glucose and fatty acids. Toll-like receptors (TLRs) are one class of pattern recognition receptors, and human adipose tissue as a whole expresses most TLRs (36). However, 3T3-L1 adipocytes are responsive only to TLR1, TLR3, TLR4, and TLR2/6 agonists but not TLR5 agonists (36). Stimulation of adipocytes with lipopolysaccharide (LPS) causes nuclear translocation of NF- $\mathrm{KB}$ and associated changes in NF-кB-responsive genes (36). Specifically, TLR ligand stimulation results in enhanced gene expression and secretion of cytokines and chemokines from adipocytes, and both c-Jun $\mathrm{NH}_{2}$-terminal kinase and mitogen-activated protein kinase signaling pathways regulate this process (35). Interestingly, the stage of adipocyte development influences the response to stimulation with TLR ligands (36). Preadipocytes exhibit the highest secretion of IL-6, while mature adipocytes exhibit the highest monocyte chemoattractant protein-1 (MCP-1) secretion. Adipocytes generated from human bone marrow mesenchymal stem cells express TLR1-10 (14). Similarly to 3T3-L1 adipocytes, adipocytes derived from mesenchymal stem cells are responsive to TLR1-4 and TLR6 agonists (14). However, these cells are also responsive to TLR5 agonists and do not respond to TLR7-9 agonists (14). Lipolysis measured by glycerol release is induced in these cells by the danger-associated molecular patterns poly(I:C) that signals through TLR3, and LPS. Interestingly, both poly(I:C) and LPS had a comparable induction of lipolysis (14). Adipocytes appear very responsive to TLR3 and TLR4 stimulation, yet it is not known whether other TLR activators would produce a comparative lipolytic response. Because there is variation in the gene expression response to these stimuli, there also are likely variations in the physiological responses.

In addition to the TLRs, nucleotide-binding oligomerization domain-containing protein (NOD)1 and -2 are also expressed in adipocytes. NOD1 and NOD2 expression is increased during adipogenesis in 3T3-L1 and primary human cells (29). Activation of NOD1 suppresses adipocyte differentiation and expression of PPAR $\gamma$, CCAAT/enhancer binding protein- $\alpha$, fatty acid binding protein-4, and leptin in a dose-dependent manner (29). NOD2 does not suppresses adipocyte differentiation in 3T3-L1 adipocytes, but it does suppress differentiation of adipose-derived adult stem cells, indicating some possible species-specific effects (29). NOD1 activation results in increased NF- $\kappa \mathrm{B}$ activity, and the expression and secretion of MCP-1 and RANTES (regulated on activation, normal T cell expressed and secreted) from 3T3-L1 adipocytes (98). Similarly, glycerol and FFA release is increased in response to NOD1 agonists (61). The lipolytic actions of NOD1 agonist are dependent on NF- $\kappa \mathrm{B}$, protein kinase A, and HSL (61). In human primary adipocytes, the same trend of increased MCP-1 and IL-6 expression is observed (98). Interestingly, NOD1/ $2^{-I-}$ mice have reduced gonadal adipose tissue mass, improved insulin sensitivity, and reduced adipocyte size and liver lipid accumulation during high-fat feeding (67). Systemic administration of NOD1 ligand (FK156) during hyperinsulinemic-euglycemic clamp studies in mice results in a reduced rate of glucose infusion and reduced glucose disposal, whereas the NOD2 ligand muramyl dipeptide had only modest effects (67).

The role of the adipocyte as a participant in the response to innate immune activators is ambiguous. However, it is obvious that there is a lipolytic response to both proinflammatory cytokines and pathogen-associated molecular patterns in adipocytes. It is intriguing that in addition to a significant lipolytic response in adipocytes there is also a global remodeling of lipid metabolism during infection. In the liver, these proinflammatory signals can shift metabolism toward fatty acid synthesis and away from fatty acid oxidation and ketogenesis (34). Lipoproteins, including very-low-density lipoprotein (VLDL), low-density lipoprotein, and high-density lipoprotein, can bind 
LPS, and this occurs in both the lipid and protein fractions of lipoproteins (34). The extent to which adipose tissue lipolysis contributes to the formation of VLDL and subsequent neutralization of pathogens is not known. Adipose tissue-derived lipid substrate may also influence the metabolism of immune cells. Cells that regulate inflammation, particularly regulatory $\mathrm{T}$ cells and M2-polarized macrophages, rely on fatty acid oxidation $(69,89)$. Thus, the lipids released from adipose tissue could support the metabolism of these cells and the resolution of inflammation. In addition to the metabolites secreted by adipose tissue, there are also a variety of adipokines that have endocrine functions. Mice that lack adiponectin have an exaggerated inflammatory response to systemic LPS administration (80), and mice that lack leptin have increased mortality in response to sepsis (9). These studies demonstrate that adipokines have the potential to influence the systemic inflammatory response (9). Adipose tissue constitutes a large portion of body mass and is an immunologically active compartment. Thiazolidinediones (TZDs) are a unique class of insulin-sensitizing drugs that increase adipogenesis and lipid storage in adipose tissue and reduce lipolysis. They have also been shown to have anti-inflammatory effects during sepsis. Yet, it is not known whether adipocytes contribute to the beneficial effects of TZDs through adiponectin secretion. Also, many of the anti-inflammatory actions attributed to TZDs may be due to their effects on leukocytes $(12,20,63)$. Future research will be needed to assess the contribution of adipose tissue to the systemic inflammatory response and distinguish the metabolic influence of adipose tissue on inflammation from its hormonal influence upon systemic inflammatory responses.

\section{Alternatively Activated Macrophages}

Although proinflammatory cytokines and pattern recognition receptors have the ability to induce insulin resistance and adipose tissue lipolysis, anti-inflammatory cytokines play a role in regulating lipolysis as well. Lipolysis is necessary to fuel thermogenesis in order to maintain body temperature during cold exposure. Most research on thermogenesis has focused on modulation by the central nervous system; however, recent evidence indicates that alternatively activated macrophages play a role in this process. It is well established that IL-4 and IL-13 are linked to the alternative activation of macrophages and signal via STAT6 (86). IL-4 signals through the IL-4 receptor, resulting in translocation of STAT6 to the nucleus and STAT6-dependent gene transcription (Fig. 2). STAT6 $^{-1-}$ mice are resistant to the development of obesity despite developing insulin resistance and glucose intolerance (64). Recent observations indicate that mice lacking IL-4 receptors on macrophages have a reduced ability to maintain core body temperature in response to a cold stimulus (51). These experiments also suggest that these cytokines do not act directly on adipocytes, but that catecholamine production by ATMs supports the lipolysis that is required for thermogenesis (51). However, others have reported direct effects of IL-4 on 3T3-L1 adipocytes to inhibit adipogenesis and increase lipolysis (82). Future studies will be needed to identify and understand the primary targets of IL-4 in adipose tissue. It is interesting that both proinflammatory and anti-inflammatory signals have the capacity to influence lipolysis in adipocytes and adipose tissue. An important discriminator of these signals is the stimuli that activate them. The IL-4 macrophage catecholamine pathway is responsive to cold stimuli and is necessary for the maintenance of core body temperature. The proinflammatory pathway is responsive to adipose tissue and systemic inflammation, which may proceed in a chronic fashion and may not be coupled to the increased oxidative capacity associated with thermogenesis.

Although IL-10 is frequently used as a measure of adipose tissue inflammatory balance, this cytokine has received a very limited amount of attention for its potential role in adipocyte regulation. IL-10 is known to inhibit the actions of $\mathrm{TNF} \alpha$ on insulin resistance and improve insulin signaling in cultured 3T3-L1 adipocytes (45). Similarly, IL-10 inhibits NF-кB activation in response to LPS (43). Its role in lipolysis may be as a negative regulator of lipolytic signaling by inflammatory stimuli rather than having direct effects. IL-10 signaling occurs through the IL-10 receptor, and, like gp130 cytokines, activates STAT3 (Fig. 2). In some circumstances, STAT3 activation appears to have proinflammatory effects on adipocytes. However, STAT3 regulation is complex, and it will be critical to determine how different signaling pathways determine the specificity of STAT3 activation. In primary human adipocytes, there is no STAT3 activation in response to IL-10, indicating that there may be species-specific differences in IL-10 signaling (83).

\section{Metabolic Flexibility and Adipose Tissue Lipolysis}

Obesity is a multifactorial disease associated with predisposition of many related comorbidities. It has been noted that healthy individuals display metabolic flexibility, with a respiratory quotient that increases in response to meals (indicating carbohydrate utilization as a fuel source) and decreases in response to fasting (indicating fatty acid oxidation as a fuel source). With the development of insulin resistance and T2DM, there is a loss of metabolic flexibility that is characterized by a respiratory quotient that has a reduced magnitude of change in response to fasting or meals (15). Loss of metabolic flexibility is accompanied by alterations in adipose tissue lipolysis (74). Increased lipolysis also occurs with increased expression of immune cell markers and proinflammatory cytokines in adipose tissue (74). These conditions are also associated with the deposition of ectopic fat in skeletal muscle and liver. NEFA themselves cause insulin resistance in skeletal muscle and can do so acutely after 2-3 days of fasting (23). Thus, strategies to control lipolysis, including pharmaceuticals directly targeted to proinflammatory cytokines (IL-1 $\beta$, TNF, etc.) that enhance fat storage and adipogenesis or that couple fatty acid oxidation to lipolysis, would be of benefit for the management of obesity and metabolic syndrome. In addition to adipose tissue inflammation, bacterial PAMPs from the gut microbiota may contribute to this process as well, because type 2 diabetics are known to have increased circulating levels of LPS (62). Modification of the gut microbiota may be an additional way to manage lipolysis and metabolic impairments during obesity.

\section{Conclusions}

With an increased understanding of the connections between immune cell function and metabolic homeostasis, it is important to understand how both cytokines and pathogen-associated 
molecular patterns affect adipocyte metabolism in order to understand the contribution of adipose tissue to acute and chronic inflammation. A growing body of literature in this area has demonstrated both pro- and antilipolytic effects of immune-related cytokines. The complex microenvironment of adipose tissue means that multiple cellular targets are present for each cytokine. Hence, cytokines are not acting singularly, and there is potential for adipocyte-secreted proteins to impact the production of proinflammatory cytokines. Thus, there remains much to be investigated in terms of production of cytokines, combinatorial effects on adipocytes, and cross-talk between adipocytes, leukocytes, and other adipose tissue cells on the influence of adipose tissue lipolysis and inflammation.

As a metabolically active tissue, adipose tissue is able to modify systemic metabolism through the provisioning of lipids and via the endocrine actions of adipokines. Free fatty acids released from adipose tissue are a fuel source during times of energy scarcity and high energy demands including exercise and cold exposure. Dysregulation of the control of lipolysis during metabolic disease contributes to dyslipidemia and the deposition of ectopic fat that impairs tissue function. The secretion of cytokines by leukocytes in adipose tissue regulates lipolysis in both physiological and pathophysiological conditions. These immunometabolic interactions have profound effects on lipolysis and present an opportunity to understand the underlying biology controlling lipolysis and pathological lipid metabolism during obesity and T2DM.

\section{ACKNOWLEDGMENTS}

We thank Ann Liu for assistance with figure preparation and design.

\section{DISCLOSURES}

No conflicts of interest, financial or otherwise, are declared by the author(s).

\section{AUTHOR CONTRIBUTIONS}

Author contributions: R.W.G. prepared figures; R.W.G. drafted manuscript; R.W.G. and J.M.S. edited and revised manuscript; J.M.S. approved final version of manuscript.

\section{REFERENCES}

1. Ajuwon KM, Spurlock ME. Direct regulation of lipolysis by interleukin-15 in primary pig adipocytes. Am J Physiol Regul Integr Comp Physiol 287: R608-R611, 2004.

2. Arner P, Langin D. Lipolysis in lipid turnover, cancer cachexia, and obesity-induced insulin resistance. Trends Endocrinol Metab 25: 255-262, 2014.

3. Botion LM, Brasier AR, Tian B, Udupi V, Green A. Inhibition of proteasome activity blocks the ability of TNF alpha to down-regulate G(i) proteins and stimulate lipolysis. Endocrinology 142: 5069-5075, 2001.

4. Chandrasekar B, Patel DN, Mummidi S, Kim JW, Clark RA, Valente AJ. Interleukin-18 suppresses adiponectin expression in 3T3-L1 adipocytes via a novel signal transduction pathway involving ERK1/2dependent NFATc4 phosphorylation. J Biol Chem 283: 4200-4209, 2008.

5. Crowe S, Turpin SM, Ke F, Kemp BE, Watt MJ. Metabolic remodeling in adipocytes promotes ciliary neurotrophic factor-mediated fat loss in obesity. Endocrinology 149: 2546-2556, 2008.

6. Danforth E Jr. Failure of adipocyte differentiation causes type II diabetes mellitus? Nat Genet 26: 13, 2000.

7. Di Gregorio GB, Hensley L, Lu T, Ranganathan G, Kern PA. Lipid and carbohydrate metabolism in mice with a targeted mutation in the IL-6 gene: absence of development of age-related obesity. Am J Physiol Endocrinol Metab 287: E182-E187, 2004.

8. Fabrizi M, Marchetti V, Mavilio M, Marino A, Casagrande V, Cavalera M, Moreno-Navarrete JM, Mezza T, Sorice GP, Fiorentino L, Menghini R, Lauro R, Monteleone G, Giaccari A, Fernandez Real JM, Federici M. IL-21 is a major negative regulator of IRF4-dependent lipolysis affecting Tregs in adipose tissue and systemic insulin sensitivity. Diabetes 63: 2086-2096, 2014.

9. Faggioni R, Fantuzzi G, Gabay C, Moser A, Dinarello CA, Feingold KR, Grunfeld C. Leptin deficiency enhances sensitivity to endotoxininduced lethality. Am J Physiol Regul Integr Comp Physiol 276: R136R142, 1999.

10. Fasnacht N, Muller W. Conditional gp130 deficient mouse mutants. Semin Cell Dev Biol 19: 379-384, 2008.

11. Feingold KR, Doerrler W, Dinarello CA, Fiers W, Grunfeld C. Stimulation of lipolysis in cultured fat cells by tumor necrosis factor, interleukin-1, and the interferons is blocked by inhibition of prostaglandin synthesis. Endocrinology 130: 10-16, 1992.

12. Ferreira AE, Sisti F, Sonego F, Wang S, Filgueiras LR, Brandt S, Serezani AP, Du H, Cunha FQ, Alves-Filho JC, Serezani CH. PPARgamma/IL-10 axis inhibits MyD88 expression and ameliorates murine polymicrobial sepsis. J Immunol 192: 2357-2365, 2014.

13. Flower L, Gray R, Pinkney J, Mohamed-Ali V. Stimulation of interleukin-6 release by interleukin-1beta from isolated human adipocytes. Cytokine 21: 32-37, 2003.

14. Franchini M, Monnais E, Seboek D, Radimerski T, Zini E, Kaufmann K, Lutz T, Reusch C, Ackermann M, Muller B, Linscheid P. Insulin resistance and increased lipolysis in bone marrow derived adipocytes stimulated with agonists of Toll-like receptors. Horm Metab Res 42: 703-709, 2010.

15. Galgani JE, Moro C, Ravussin E. Metabolic flexibility and insulin resistance. Am J Physiol Endocrinol Metab 295: E1009-E1017, 2008.

16. Gasic S, Tian B, Green A. Tumor necrosis factor alpha stimulates lipolysis in adipocytes by decreasing $\mathrm{Gi}$ protein concentrations. J Biol Chem 274: 6770-6775, 1999.

17. Green A, Dobias SB, Walters DJ, Brasier AR. Tumor necrosis factor increases the rate of lipolysis in primary cultures of adipocytes without altering levels of hormone-sensitive lipase. Endocrinology 134: 25812588, 1994.

18. Green A, Rumberger JM, Stuart CA, Ruhoff MS. Stimulation of lipolysis by tumor necrosis factor-alpha in 3T3-L1 adipocytes is glucose dependent: implications for long-term regulation of lipolysis. Diabetes 53: 74-81, 2004.

19. Guarda G, Zenger M, Yazdi AS, Schroder K, Ferrero I, Menu P, Tardivel A, Mattmann C, Tschopp J. Differential expression of NLRP3 among hematopoietic cells. J Immunol 186: 2529-2534, 2011.

20. Haraguchi G, Kosuge H, Maejima Y, Suzuki J, Imai T, Yoshida M, Isobe M. Pioglitazone reduces systematic inflammation and improves mortality in apolipoprotein E knockout mice with sepsis. Intensive Care Med 34: 1304-1312, 2008.

21. He J, Usui I, Ishizuka K, Kanatani Y, Hiratani K, Iwata M, Bukhari A, Haruta T, Sasaoka T, Kobayashi M. Interleukin-1alpha inhibits insulin signaling with phosphorylating insulin receptor substrate-1 on serine residues in 3T3-L1 adipocytes. Mol Endocrinol 20: 114-124, 2006.

22. Heinrich PC, Behrmann I, Haan S, Hermanns HM, Muller-Newen G, Schaper F. Principles of interleukin (IL)-6-type cytokine signalling and its regulation. Biochem J 374: 1-20, 2003.

23. Hoeks J, van Herpen NA, Mensink M, Moonen-Kornips E, van Beurden D, Hesselink MK, Schrauwen P. Prolonged fasting identifies skeletal muscle mitochondrial dysfunction as consequence rather than cause of human insulin resistance. Diabetes 59: 2117-2125, 2010.

24. Honnor RC, Dhillon GS, Londos C. cAMP-dependent protein kinase and lipolysis in rat adipocytes. II. Definition of steady-state relationship with lipolytic and antilipolytic modulators. J Biol Chem 260: 1513015138,1985

25. Hotamisligil GS, Arner P, Caro JF, Atkinson RL, Spiegelman BM. Increased adipose tissue expression of tumor necrosis factor-alpha in human obesity and insulin resistance. J Clin Invest 95: 2409-2415, 1995.

26. Hotamisligil GS, Budavari A, Murray D, Spiegelman BM. Reduced tyrosine kinase activity of the insulin receptor in obesity-diabetes. Central role of tumor necrosis factor-alpha. J Clin Invest 94: 1543-1549, 1994.

27. Hotamisligil GS, Murray DL, Choy LN, Spiegelman BM. Tumor necrosis factor alpha inhibits signaling from the insulin receptor. Proc Natl Acad Sci USA 91: 4854-4858, 1994.

28. Hotamisligil GS, Shargill NS, Spiegelman BM. Adipose expression of tumor necrosis factor-alpha: direct role in obesity-linked insulin resistance. Science 259: 87-91, 1993.

29. JSP, Hu P, Burke SJ, Collier JJ, Chen J, Zhao L. The effects of NOD activation on adipocyte differentiation. Obesity (Silver Spring) 21: 737$747,2013$. 
30. Ji C, Chen X, Gao C, Jiao L, Wang J, Xu G, Fu H, Guo X, Zhao Y. IL-6 induces lipolysis and mitochondrial dysfunction, but does not affect insulin-mediated glucose transport in 3T3-L1 adipocytes. J Bioenerg Biomembr 43: 367-375, 2011.

31. Karelis AD, Faraj M, Bastard JP, St-Pierre DH, Brochu M, Prud'homme D, Rabasa-Lhoret R. The metabolically healthy but obese individual presents a favorable inflammation profile. J Clin Endocrinol Metab 90: 4145-4150, 2005.

32. Kawakami M, Murase T, Ogawa H, Ishibashi S, Mori N, Takaku F, Shibata S. Human recombinant TNF suppresses lipoprotein lipase activity and stimulates lipolysis in 3T3-L1 cells. J Biochem 101: 331-338, 1987.

33. Khan T, Muise ES, Iyengar $\mathbf{P}$, Wang ZV, Chandalia M, Abate $\mathbf{N}$, Zhang BB, Bonaldo P, Chua S, Scherer PE. Metabolic dysregulation and adipose tissue fibrosis: role of collagen VI. Mol Cell Biol 29: 1575-1591, 2009.

34. Khovidhunkit W, Kim MS, Memon RA, Shigenaga JK, Moser AH, Feingold KR, Grunfeld C. Effects of infection and inflammation on lipid and lipoprotein metabolism: mechanisms and consequences to the host. $J$ Lipid Res 45: 1169-1196, 2004.

35. Kopp A, Buechler C, Bala M, Neumeier M, Scholmerich J, Schaffler A. Toll-like receptor ligands cause proinflammatory and prodiabetic activation of adipocytes via phosphorylation of extracellular signal-regulated kinase and c-Jun N-terminal kinase but not interferon regulatory factor-3. Endocrinology 151: 1097-1108, 2010.

36. Kopp A, Buechler C, Neumeier M, Weigert J, Aslanidis C, Scholmerich J, Schaffler A. Innate immunity and adipocyte function: ligandspecific activation of multiple Toll-like receptors modulates cytokine, adipokine, and chemokine secretion in adipocytes. Obesity (Silver Spring) 17: 648-656, 2009.

37. Kosteli A, Sugaru E, Haemmerle G, Martin JF, Lei J, Zechner R, Ferrante AW Jr. Weight loss and lipolysis promote a dynamic immune response in murine adipose tissue. J Clin Invest 120: 3466-3479, 2010.

38. Koster A, Stenholm S, Alley DE, Kim LJ, Simonsick EM, Kanaya AM, Visser M, Houston DK, Nicklas BJ, Tylavsky FA, Satterfield S, Goodpaster BH, Ferrucci L, Harris TB. Body fat distribution and inflammation among obese older adults with and without metabolic syndrome. Obesity (Silver Spring) 18: 2354-2361, 2010.

39. Lagathu C, Yvan-Charvet L, Bastard JP, Maachi M, QuignardBoulange A, Capeau J, Caron M. Long-term treatment with interleukin1 beta induces insulin resistance in murine and human adipocytes. Diabetologia 49: 2162-2173, 2006.

40. Lamkanfi M, Mueller JL, Vitari AC, Misaghi S, Fedorova A, Deshayes K, Lee WP, Hoffman HM, Dixit VM. Glyburide inhibits the Cryopyrin/Nalp3 inflammasome. J Cell Biol 187: 61-70, 2009.

41. Laurencikiene J, van Harmelen V, Arvidsson Nordstrom E, Dicker A, Blomqvist L, Naslund E, Langin D, Arner P, Ryden M. NF-kappaB is important for TNF-alpha-induced lipolysis in human adipocytes. J Lipid Res 48: 1069-1077, 2007.

42. Lionetti L, Mollica MP, Lombardi A, Cavaliere G, Gifuni G, Barletta A. From chronic overnutrition to insulin resistance: the role of fat-storing capacity and inflammation. Nutr Metab Cardiovasc Dis 19: 146-152, 2009.

43. Lira FS, Rosa JC, Pimentel GD, Seelaender M, Damaso AR, Oyama LM, do Nascimento CO. Both adiponectin and interleukin-10 inhibit LPS-induced activation of the NF-kappaB pathway in 3T3-L1 adipocytes. Cytokine 57: 98-106, 2012.

44. Lopez-Yoldi M, Fernandez-Galilea M, Laiglesia LM, Larequi E, Prieto J, Martinez JA, Bustos M, Moreno-Aliaga MJ. Cardiotrophin-1 stimulates lipolysis through the regulation of main adipose tissue lipases. J Lipid Res 55: 2634-2643, 2014.

45. Lumeng CN, Bodzin JL, Saltiel AR. Obesity induces a phenotypic switch in adipose tissue macrophage polarization. J Clin Invest 117: 175-184, 2007.

46. Lumeng CN, Deyoung SM, Saltiel AR. Macrophages block insulin action in adipocytes by altering expression of signaling and glucose transport proteins. Am J Physiol Endocrinol Metab 292: E166-E174, 2007.

47. Marques-Vidal P, Velho S, Waterworth D, Waeber G, von Kanel R, Vollenweider P. The association between inflammatory biomarkers and metabolically healthy obesity depends of the definition used. Eur J Clin Nutr 66: 426-435, 2012.

48. Marshall MK, Doerrler W, Feingold KR, Grunfeld C. Leukemia inhibitory factor induces changes in lipid-metabolism in cultured adipocytes. Endocrinology 135: 141-147, 1994.
49. Moreno-Aliaga MJ, Romero-Lozano MA, Castano D, Prieto J, Bustos M. Role of cardiotrophin-1 in obesity and insulin resistance. Adipocyte 1: 112-115, 2012.

50. Netea MG, Joosten LA, Lewis E, Jensen DR, Voshol PJ, Kullberg BJ, Tack CJ, van Krieken H, Kim SH, Stalenhoef AF, van de Loo FA, Verschueren I, Pulawa L, Akira S, Eckel RH, Dinarello CA, van den Berg W, van der Meer JW. Deficiency of interleukin-18 in mice leads to hyperphagia, obesity and insulin resistance. Nat Med 12: 650-656, 2006.

51. Nguyen KD, Qiu Y, Cui X, Goh YP, Mwangi J, David T, Mukundan L, Brombacher F, Locksley RM, Chawla A. Alternatively activated macrophages produce catecholamines to sustain adaptive thermogenesis. Nature 480: 104-108, 2011.

52. Nielsen TS, Jessen N, Jorgensen JO, Moller N, Lund S. Dissecting adipose tissue lipolysis: molecular regulation and implications for metabolic disease. J Mol Endocrinol 52: R199-R222, 2014.

53. Osborn O, Olefsky JM. The cellular and signaling networks linking the immune system and metabolism in disease. Nat Med 18: 363-374, 2012.

54. Pedersen BK, Febbraio MA. Muscles, exercise and obesity: skeletal muscle as a secretory organ. Nat Rev Endocrinol 8: 457-465, 2012.

55. Peraldi P, Hotamisligil GS, Buurman WA, White MF, Spiegelman BM. Tumor necrosis factor (TNF)-alpha inhibits insulin signaling through stimulation of the p55 TNF receptor and activation of sphingomyelinase. J Biol Chem 271: 13018-13022, 1996.

56. Petersen EW, Carey AL, Sacchetti M, Steinberg GR, Macaulay SL, Febbraio MA, Pedersen BK. Acute IL-6 treatment increases fatty acid turnover in elderly humans in vivo and in tissue culture in vitro. $\mathrm{Am} J$ Physiol Endocrinol Metab 288: E155-E162, 2005.

57. Phillips CM. Metabolically healthy obesity: definitions, determinants and clinical implications. Rev Endocrinol Metab Disord 14: 219-227, 2013.

58. Phillips CM, Perry IJ. Does inflammation determine metabolic health status in obese and nonobese adults? J Clin Endocrinol Metab 98: E1610-E1619, 2013.

59. Pickup JC, Mattock MB, Chusney GD, Burt D. NIDDM as a disease of the innate immune system: association of acute-phase reactants and interleukin-6 with metabolic syndrome X. Diabetologia 40: 1286-1292, 1997.

60. Price SR, Mizel SB, Pekala PH. Regulation of lipoprotein lipase synthesis and 3T3-L1 adipocyte metabolism by recombinant interleukin 1 . Biochim Biophys Acta 889: 374-381, 1986.

61. Purohit JS, Hu P, Chen G, Whelan J, Moustaid-Moussa N, Zhao L. Activation of nucleotide oligomerization domain containing protein 1 induces lipolysis through NF-kappaB and the lipolytic PKA activation in 3T3-L1 adipocytes. Biochem Cell Biol 91: 428-434, 2013.

62. Pussinen PJ, Havulinna AS, Lehto M, Sundvall J, Salomaa V. Endotoxemia is associated with an increased risk of incident diabetes. Diabetes Care 34: 392-397, 2011.

63. Reynolds K, Novosad B, Hoffhines A, Gipson J, Johnson J, Peters J, Gonzalez F, Gimble J, Hill M. Pretreatment with troglitazone decreases lethality during endotoxemia in mice. J Endotoxin Res 8: 307-314, 2002.

64. Ricardo-Gonzalez RR, Red Eagle A, Odegaard JI, Jouihan H, Morel CR, Heredia JE, Mukundan L, Wu D, Locksley RM, Chawla A. IL-4/STAT6 immune axis regulates peripheral nutrient metabolism and insulin sensitivity. Proc Natl Acad Sci USA 107: 22617-22622, 2010.

65. Rosenbaum SE, Greenberg AS. The short- and long-term effects of tumor necrosis factor-alpha and BRL 49653 on peroxisome proliferatoractivated receptor (PPAR)gamma2 gene expression and other adipocyte genes. Mol Endocrinol 12: 1150-1160, 1998.

66. Sanchez-Infantes D, White UA, Elks CM, Morrison RF, Gimble JM, Considine RV, Ferrante AW, Ravussin E, Stephens JM. Oncostatin M is produced in adipose tissue and is regulated in conditions of obesity and type 2 diabetes. J Clin Endocrinol Metab jc20133555, 2013.

67. Schertzer JD, Tamrakar AK, Magalhaes JG, Pereira S, Bilan PJ, Fullerton MD, Liu Z, Steinberg GR, Giacca A, Philpott DJ, Klip A. NOD1 activators link innate immunity to insulin resistance. Diabetes 60: 2206-2215, 2011

68. Schroder K, Tschopp J. The inflammasomes. Cell 140: 821-832, 2010.

69. Shi LZ, Wang R, Huang G, Vogel P, Neale G, Green DR, Chi H. HIF1alpha-dependent glycolytic pathway orchestrates a metabolic checkpoint for the differentiation of TH17 and Treg cells. J Exp Med 208: 1367-1376, 2011.

70. Shin JH, Shin DW, Noh M. Interleukin-17A inhibits adipocyte differentiation in human mesenchymal stem cells and regulates pro-inflammatory responses in adipocytes. Biochem Pharmacol 77: 1835-1844, 2009. 
71. Souza SC, de Vargas LM, Yamamoto MT, Lien P, Franciosa MD, Moss LG, Greenberg AS. Overexpression of perilipin A and B blocks the ability of tumor necrosis factor alpha to increase lipolysis in 3T3-L1 adipocytes. J Biol Chem 273: 24665-24669, 1998.

72. Souza SC, Palmer HJ, Kang YH, Yamamoto MT, Muliro KV, Paulson KE, Greenberg AS. TNF-alpha induction of lipolysis is mediated through activation of the extracellular signal related kinase pathway in 3T3-L1 adipocytes. J Cell Biochem 89: 1077-1086, 2003.

73. Souza SC, Yamamoto MT, Franciosa MD, Lien P, Greenberg AS. BRL 49653 blocks the lipolytic actions of tumor necrosis factor-alpha: a potential new insulin-sensitizing mechanism for thiazolidinediones. Diabetes 47: 691-695, 1998.

74. Sparks LM, Ukropcova B, Smith J, Pasarica M, Hymel D, Xie H, Bray GA, Miles JM, Smith SR. Relation of adipose tissue to metabolic flexibility. Diabetes Res Clin Pract 83: 32-43, 2009.

75. Stephens JM, Lee J, Pilch PF. Tumor necrosis factor-alpha-induced insulin resistance in 3T3-L1 adipocytes is accompanied by a loss of insulin receptor substrate-1 and GLUT4 expression without a loss of insulin receptor-mediated signal transduction. J Biol Chem 272: 971-976, 1997.

76. Stephens JM, Pekala PH. Transcriptional repression of the GLUT4 and $\mathrm{C} / \mathrm{EBP}$ genes in 3T3-L1 adipocytes by tumor necrosis factor-alpha. $J$ Biol Chem 266: 21839-21845, 1991.

77. Stienstra R, Joosten LA, Koenen T, van Tits B, van Diepen JA, van den Berg SA, Rensen PC, Voshol PJ, Fantuzzi G, Hijmans A, Kersten S, Muller M, van den Berg WB, van Rooijen N, Wabitsch M, Kullberg BJ, van der Meer JW, Kanneganti T, Tack CJ, Netea MG. The inflammasome-mediated caspase-1 activation controls adipocyte differentiation and insulin sensitivity. Cell Metab 12: 593-605, 2010.

78. Stienstra R, van Diepen JA, Tack CJ, Zaki MH, van de Veerdonk FL, Perera D, Neale GA, Hooiveld GJ, Hijmans A, Vroegrijk I, van den Berg S, Romijn J, Rensen PC, Joosten LA, Netea MG, Kanneganti TD. Inflammasome is a central player in the induction of obesity and insulin resistance. Proc Natl Acad Sci USA 108: 15324-15329, 2011.

79. Strissel KJ, Stancheva Z, Miyoshi H, Perfield JW, 2nd DeFuria J, Jick Z, Greenberg AS, Obin MS. Adipocyte death, adipose tissue remodeling, and obesity complications. Diabetes 56: 2910-2918, 2007.

80. Teoh H, Quan A, Bang KW, Wang G, Lovren F, Vu V, Haitsma JJ, Szmitko PE, Al-Omran M, Wang CH, Gupta M, Peterson MD, Zhang H, Chan L, Freedman J, Sweeney G, Verma S. Adiponectin deficiency promotes endothelial activation and profoundly exacerbates sepsis-related mortality. Am J Physiol Endocrinol Metab 295: E658-E664, 2008.

81. Torti FM, Torti SV, Larrick JW, Ringold GM. Modulation of adipocyte differentiation by tumor necrosis factor and transforming growth factor beta. J Cell Biol 108: 1105-1113, 1989.

82. Tsao CH, Shiau MY, Chuang PH, Chang YH, Hwang J. Interleukin-4 regulates lipid metabolism by inhibiting adipogenesis and promoting lipolysis. J Lipid Res 55: 385-397, 2014.

83. Turner JJ, Foxwell KM, Kanji R, Brenner C, Wood S, Foxwell BM, Feldmann M. Investigation of nuclear factor-kappaB inhibitors and interleukin-10 as regulators of inflammatory signalling in human adipocytes. Clin Exp Immunol 162: 487-493, 2010.

84. Uno T, He J, Usui I, Kanatani Y, Bukhari A, Fujisaka S, Yamazaki Y, Suzuki H, Iwata M, Ishiki M, Urakaze M, Haruta T, Ogawa H, Kobayashi M. Long-term interleukin-1alpha treatment inhibits insulin signaling via IL-6 production and SOCS3 expression in 3T3-L1 adipocytes. Horm Metab Res 40: 8-12, 2008.
85. Uysal KT, Wiesbrock SM, Marino MW, Hotamisligil GS. Protection from obesity-induced insulin resistance in mice lacking TNF-alpha function. Nature 389: 610-614, 1997.

86. Van Dyken SJ, Locksley RM. Interleukin-4- and interleukin-13-mediated alternatively activated macrophages: roles in homeostasis and disease. Annu Rev Immunol 31: 317-343, 2013.

87. van Hall G, Steensberg A, Sacchetti M, Fischer C, Keller C, Schjerling P, Hiscock N, Moller K, Saltin B, Febbraio MA, Pedersen BK. Interleukin-6 stimulates lipolysis and fat oxidation in humans. J Clin Endocrinol Metab 88: 3005-3010, 2003.

88. Vandanmagsar B, Youm YH, Ravussin A, Galgani JE, Stadler K, Mynatt RL, Ravussin E, Stephens JM, Dixit VD. The NLRP3 inflammasome instigates obesity-induced inflammation and insulin resistance. Nat Med 17: 179-188, 2011.

89. Vats D, Mukundan L, Odegaard JI, Zhang L, Smith KL, Morel CR, Wagner RA, Greaves DR, Murray PJ, Chawla A. Oxidative metabolism and PGC-1beta attenuate macrophage-mediated inflammation. Cell Metab 4: 13-24, 2006.

90. Vazquez-Carballo A, Ceperuelo-Mallafre V, Chacon MR, MaymoMasip E, Lorenzo M, Porras A, Vendrell J, Fernandez-Veledo S. TWEAK prevents TNF- $\alpha$-induced insulin resistance through PP2A activation in human adipocytes. Am J Physiol Endocrinol Metab 305: E101E112, 2013.

91. Vgontzas AN, Papanicolaou DA, Bixler EO, Kales A, Tyson K, Chrousos GP. Elevation of plasma cytokines in disorders of excessive daytime sleepiness: role of sleep disturbance and obesity. J Clin Endocrinol Metab 82: 1313-1316, 1997.

92. Wallenius V, Wallenius K, Ahren B, Rudling M, Carlsten H, Dickson SL, Ohlsson C, Jansson JO. Interleukin-6-deficient mice develop mature-onset obesity. Nat Med 8: 75-79, 2002.

93. Weisberg SP, McCann D, Desai M, Rosenbaum M, Leibel RL, Ferrante $\mathbf{A W} \mathbf{J r}$. Obesity is associated with macrophage accumulation in adipose tissue. J Clin Invest 112: 1796-1808, 2003.

94. Wen H, Gris D, Lei Y, Jha S, Zhang L, Huang MT, Brickey WJ, Ting JP. Fatty acid-induced NLRP3-ASC inflammasome activation interferes with insulin signaling. Nat Immunol 12: 408-415, 2011.

95. Wernstedt I, Edgley A, Berndtsson A, Faldt J, Bergstrom G, Wallenius V, Jansson JO. Reduced stress- and cold-induced increase in energy expenditure in interleukin-6-deficient mice. Am J Physiol Regul Integr Comp Physiol 291: R551-R557, 2006.

96. Yang X, Zhang X, Heckmann BL, Lu X, Liu J. Relative contribution of adipose triglyceride lipase and hormone-sensitive lipase to tumor necrosis factor-alpha (TNF-alpha)-induced lipolysis in adipocytes. $\mathrm{J}$ Biol Chem 286: 40477-40485, 2011.

97. Zhang HH, Halbleib M, Ahmad F, Manganiello VC, Greenberg AS. Tumor necrosis factor-alpha stimulates lipolysis in differentiated human adipocytes through activation of extracellular signal-related kinase and elevation of intracellular cAMP. Diabetes 51: 2929-2935, 2002.

98. Zhao L, Hu P, Zhou Y, Purohit J, Hwang D. NOD1 activation induces proinflammatory gene expression and insulin resistance in 3T3-L1 adipocytes. Am J Physiol Endocrinol Metab 301: E587-E598, 2011.

99. Zhou R, Tardivel A, Thorens B, Choi I, Tschopp J. Thioredoxininteracting protein links oxidative stress to inflammasome activation. Nat Immunol 11: 136-140, 2010. 